\title{
FIELD EXPERIMENTAL EVALUATION OF SECONDARY METABOLITES FROM MARINE INVERTEBRATES AS ANTIFOULANTS
}

\author{
PEREIRA, R. C., ${ }^{1}$ CARVALHO, A. G. V., ${ }^{1}$ GAMA, B. A. P. ${ }^{1}$ and COUTINHO, R. ${ }^{2}$ \\ ${ }^{1}$ Departamento de Biologia Marinha, Universidade Federal Fluminense (UFF), \\ C.P. 100.644, CEP 24001-970, Niterói, RJ, Brazil \\ ${ }^{2}$ Instituto de Estudos do Mar Almirante Paulo Moreira (IEAPM), R. Kioto, 253, \\ CEP 28930-000, Arraial do Cabo, RJ, Brazil \\ Correspondence to: Renato C. Pereira, Departamento de Biologia Marinha, Instituto de Biologia, Universidade \\ Federal Fluminense (UFF), C.P. 100.644, CEP 24001-970, Niterói, RJ, Brazil, e-mail egbrecp@vm.uff.br \\ Received April 18, 2001 - Accepted July 12, 2001 - Distributed May 31, 2002
}

(With 7 figures)

\begin{abstract}
The crude organic extracts of the endemic gorgonian Phyllogorgia dilatata and two sponge species Aplysina fulva and Mycale microsigmatosa were evaluated for anti-fouling properties through field experiments. To investigate this property in ecologically meaningful conditions, crude extracts from these invertebrates were incorporated at concentrations naturally found in these marine organisms into a stable gel used as a substratum for fouling settlement. Crude extract from A. fulva showed no significant anti-fouling property at the natural concentrations used in the field experiments. In fact, fouling organisms settled significantly more on gels treated with $A$. fulva extract than on the control gel. On the other hand, both M. microsigmatosa and $P$. dilatata yielded crude extracts that exhibited a selective action inhibiting only the settlement of barnacles. The evidences obtained here by means of field experiments can provide a basis for future development of one kind of natural antifoulant technology to prevent marine biofouling.
\end{abstract}

Key words: marine invertebrates, anti-fouling, secondary metabolites.

\section{RESUMO}

Avaliação experimental de metabólitos secundários de invertebrados marinhos como antiincrustantes em campo

As propriedades antiincrustantes dos extratos brutos da gorgônia endêmica Phyllogorgia dilatata e de duas espécies de esponja, Aplysina fulva e Mycale microsigmatosa, foram avaliadas por intermédio de ensaios de campo. Para investigar essas propriedades sob condições ecologicamente relevantes, as concentrações naturais dos extratos brutos encontrados nesses invertebrados foram incorporadas a um gel estável que serviu de substrato para o assentamento de organismos incrustantes. O extrato bruto de A. fulva não mostrou efeito antiincrustante na concentração natural usada nos experimentos. De fato, os organismos incrustantes colonizaram significativamente mais o gel contendo extrato de A. fulva do que o gel-controle. Por outro lado, ambos os invertebrados, M. microsigmatosa e P. dilatata, produzem extratos brutos que foram seletivamente ativos contra o estabelecimento de balanídeos. As evidências obtidas aqui, por meio de experimentos em campo, podem ser importantes subsídios para futuras investigações visando à aplicação industrial de produtos naturais antiincrustantes em tecnologias de prevenção da bioincrustação marinha.

Palavras-chave: invertebrados marinhos, antiincrustação, metabólitos secundários. 


\section{INTRODUCTION}

Marine biofouling is a result of bacterial growth, algae and sessile invertebrates on submerged surfaces, both natural and man-made. Despite being a natural process, fouling is currently one of the most important problems facing marine technology (Gerhart et al., 1988; Callow, 1986). Fouling organisms may colonize man-made structures, creating problems such as surface alteration (Davis et al., 1989; Safriel et al., 1993), speed reduction and increase of fuel consumption of ships (Champ \& Lowenstein, 1992; WHOI, 1967), or corrosion, weight increase and distortion of the initial configuration of submerged structures (WHOI, 1967).

Marine benthic organisms also constitute potential substrates for fouling organism settlement, including growth of bacteria, algae and invertebrates (Wahl, 1989; Uriz et al., 1992; Willemsen, 1996). However, benthic marine organisms have developed a great variety of potential defenses against fouling organisms, including possession of spines (Dyrinda, 1986; Davis et al., 1989), surface sloughing (Davis et al., 1989), production of mucus (Dyrinda, 1986; Davis et al., 1989), low surface energy (Targett, 1988; Davis et al., 1989; Wahl, 1989; Davis \& Wright, 1990), and the production of secondary metabolites (Pawlik, 1992). Marine secondary metabolites exhibiting antifouling properties have been isolated from several marine organisms including bacteria, seaweeds, seagrasses, sponges, ascidians, bryozoans, and gorgonians (Davis et al., 1989; Clare, 1996).

In addition to benthic organisms protection against fouling, marine secondary metabolites could possibly provide an alternative to the commercial metal-based antifouling coatings that are in use today (Michalek \& Bowden, 1997). In fact, secondary metabolites produced by marine sessile organisms, like seaweeds, corals and sponges, represent a new perspective on preventing overgrowth by epibionts and could potentially be used as commercial anti-foulants (Willemsen \& Ferrari, 1993). This idea is not necessarily new (see Bakus et al., 1985; Gerhart et al., 1988; Davis et al., 1989; Pawlik, 1992), but here we approach the concepts as an environmentally safe alternative to currently used commercial anti-foulants. Considering the environmental hazards involved in traditional antifouling coatings based both on heavy metals and broadly toxic biocides, it becomes necessary to find an alternative as non-toxic technologies to control marine biofouling.

A vast range of substances has been described (and patented) as anti-foulants, although the majority of tests have been laboratory-based, using the larvae of fouling organisms such as barnacles and bryozoans (Rittschof et al., 1986; Davis \& Wright, 1990; Sears et al., 1990; Martin \& Uriz, 1993; Willemsen, 1994, 1996; De Nys et al., 1995). Only a small part of the scientific community working in this area has been conducting ecologically relevant experiments, i.e., field assays, which expose test surfaces to the colonization of a natural community of settling organisms using natural concentrations of metabolites found in source organisms (Gerhart, 1986; Bingham \& Young, 1991; Henrikson \& Pawlik, 1995; Da Gama et al., 2002).

In fact, mechanisms by which marine organisms inhibit the establishment of fouling can be investigated at a variety of levels, from the molecular to the ecological (Steinberg et al., 1998). From a molecular perspective, marine secondary metabolites appear to inhibit bacterial colonization by interfering with bacterial AHL-acylated homoserine lactone regulatory processes (Kjelleberg et al., 1997). In a biological approach, a settlement of foulers on gels containing extracts of marine organisms is measured under to field conditions (Henrikson \& Pawlik, 1995, 1998).

In the present study we have evaluated the anti-fouling properties of secondary metabolites extracted from marine invertebrates through field assays.

\section{MATERIAL AND METHODS}

\section{Organisms}

Samples of marine invertebrates were collected at Cabo Frio Island, Rio de Janeiro State, including the endemic gorgonian Phyllogorgia dilatata and the sponges Aplysina fulva and Mycale microsigmatosa. These three species were chosen because they are known to produce a vast array of secondary metabolites (Faulkner, 2001 and other authors' reviews cited therein) and are very abundant in the region and apparently free of epibionts (the authors, pers. observ.). After collected, these invertebrates were washed in seawater in the laboratory (Marine Station of the Institute of Marine Studies 
Almirante Paulo Moreira, Arraial do Cabo, Rio de Janeiro State) to eliminate associated organisms.

\section{Extraction procedures}

Before the extraction procedures, the biological material was dried in the dark and at room temperature to avoid photolysis and thermo-degradation of the secondary metabolites. Portions of the specimens were used for obtaining volume through displacement using a graduated, heavy, dry test tube and were weighed again to obtain the dry weight. Wet: dry weight ratios were determined for each species. The three invertebrate species were then submitted to exhaustive and successive extractions in a combination of organic solvents (dichloromethane and methanol, DCM:MeOH), in the proportion of $2: 1$, following standard natural products chemistry procedures. To increase the effectiveness of extraction, the invertebrates in the aforementioned solvents were submitted to ultrasound for 15 minutes (Branson model 3210). The solvent was eliminated in a rotating evaporator under reduced pressure to determine the natural extract concentration for each species.

\section{Field assays}

The field assays were done according to Henrikson \& Pawlik (1995), with some innovations (Da Gama et al., 2002). The hardened gel used as substratum was maintained in the mold, so as to allow only one of the faces of the plates to loose extracts via diffusion. Only one side of the gel was exposed to the currents to reduce the diffusion rate of the extracts, standardizing the equivalent volume to $35 \mathrm{ml}$ of extracted biological material. This methodology was developed to assess two fundamental aspects of the bioassay for biofouling effects.

First, the extract is totally incorporated into the medium and is not exposed on only one surface, thereby simulating natural situations, where the products are within the organism. Secondly, it is liberated slowly, as it presumably occurs in live organisms.

Circular plastic plates containing phytage ${ }^{\mathrm{TM}}$ (Sigma Chemical Co.) were used. Extracts of the invertebrates were added to some of the plates (treatments) while only solvent was added to others (controls). Control plates $(n=6)$ were prepared with a mixture of $1.52 \mathrm{~g}$ phytagel with $35 \mathrm{ml}$ of distilled water, followed by heating to boiling point in a microwave oven. The mixture was then vigorously stirred with a glass rod, while adding 0.5 $\mathrm{ml}$ methanol and pouring it into a circular mold (Petri dish) for hardening. In the treatments $(n=6)$ an aliquot of the extract to be tested was mixed with the solution (diluted in $0.5 \mathrm{ml}$ methanol) after cooling to $\leq 60^{\circ} \mathrm{C}$. The extract added to each 35 $\mathrm{ml}$ gel was the natural equivalent of the extraction of $35 \mathrm{ml}$ of live material, in an attempt to reproduce the concentrations of the metabolites in the source organisms (natural concentration by volume).

Establishment of fouling was measured as percent-cover using a dot-grid method (Foster et al., 1991; Henrikson \& Pawlik, 1995). A high number of points (236) were used to avoid underestimating rare species and to reduce deviation among replicates (Dethier et al., 1993).

\section{Extract degradation}

To ensure that there were no substances in the crude extracts, which were artifacts from degradation after heating, we performed thin layer chromatography (TLC) on each extract, before and after heating to $80-100^{\circ} \mathrm{C}$. Generation of artifacts is a well-known subject in the natural products chemistry literature (see Cronin et al., 1995).

\section{Statistical analysis}

Analysis of variance (ANOVA) and Tukey's Honestly Significant Difference (HSD) were used to test for differences among percent cover of fouling on the treatments.

\section{RESULTS}

\section{Total cover}

In general, two distinct stages encompassing the initial establishment of microfouling were observed, followed by colonization of macroscopic organisms (macrofouling). With respect to total cover of fouling through time (Fig. 1), there were not very significant differences of mean percent cover among treatments over the weeks (ANOVA, p > 0.05). In fact, a pairwise comparison by TukeyHSD demonstrated that gels containing extract of $P$. dilatata had less settlement of fouling organisms in two weeks $\left(4^{\text {th }}\right.$ and $\left.5^{\text {th }}\right)$, while gels containing extracts of both A. fulva and M. microsigmatosa had total covers similar to control gels. 


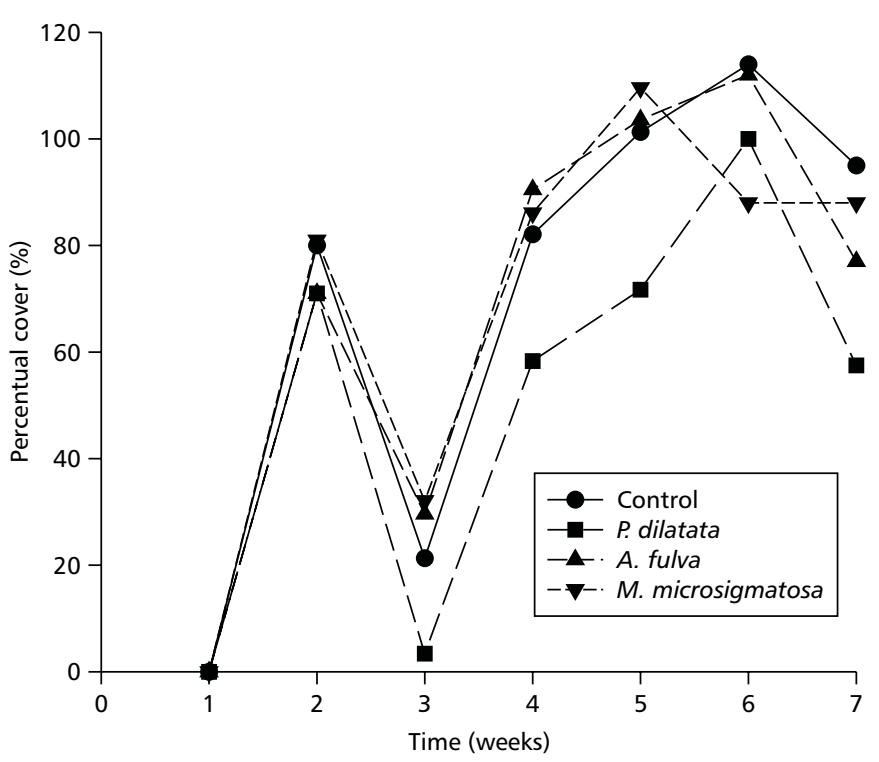

Fig. 1 - Total percent cover of fouling on control and experimental plates over seven weeks of experiment.

\section{Cover by organism groups}

In this analysis only selected species presenting more than $10 \%$ percent cover in one week or significant differences in more than one week (ANOVA, and HSD Tukey test) were used. Accordingly, Figs. 2 to 7 present changes in percent cover of organism groups such as biofilm, barnacles, the brown alga Colpomenia, coralline algae, and Dictyotacean and Ectocarpacean algae.

The biofilm, presumably including unidentified microscopic organisms such as bacteria, microalgae, and protozoans, reached a mean maximum of $75 \%$ coverage at about the second week in all treatments (Fig. 2). Biofilm covers were similar among all treatments $(\mathrm{p}>0.05)$.

More apparent and measurable covers of barnacles were observed only after 3 weeks of experiment in all treatments (Fig. 3). After 4 weeks, both treatments containing extracts of $P$. dilatata and $M$. microsigmatosa had a significantly smaller cover of barnacles than both A. fulva extract and the control $(\mathrm{p}<0.05)$.

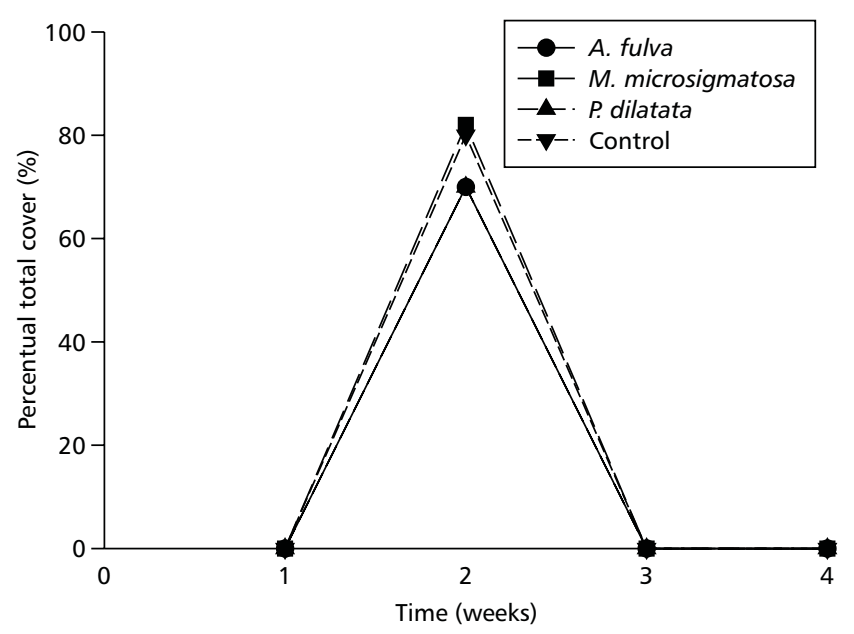

Fig. 2 - Percent cover of biofilm on control and experimental plates over seven weeks of experiment. 


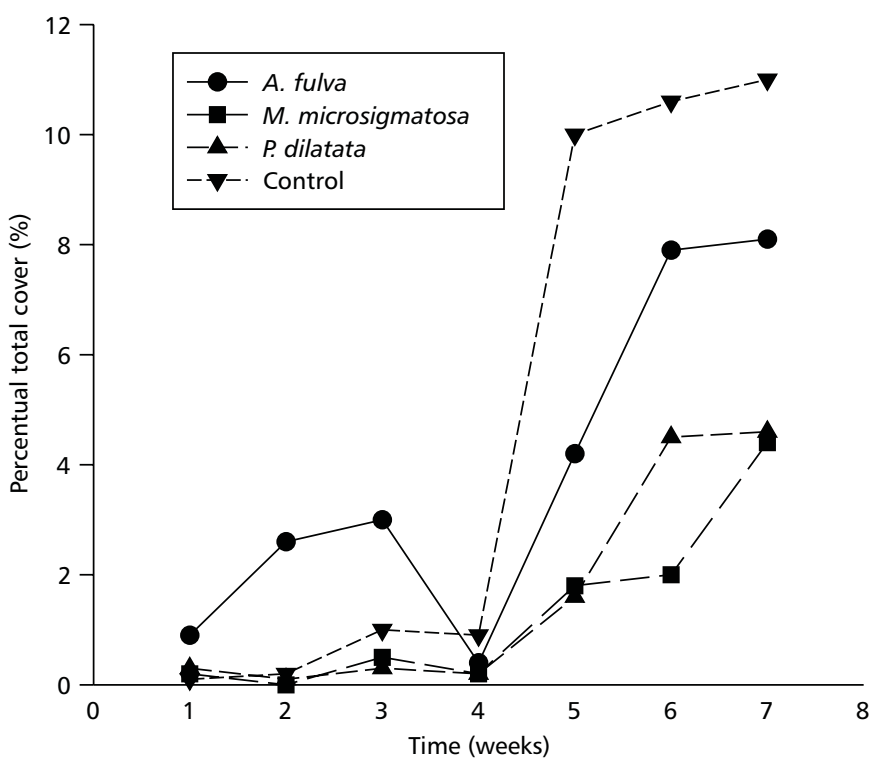

Fig. 3 - Percent cover of barnacles on control and experimental plates over seven weeks of experiment.

Only after 3 weeks was cover by the brown alga Colpomenia observed in all treatments (Fig. $4)$. In the $5^{\text {th }}$ week, higher but not significant difference $(p>0.05)$ in percentage cover of Colpomenia was observed in plates containing extracts of $A$. fulva and $M$. microsigmatosa compared to control or plates containing extracts of the gorgonian $P$. dilatata.

Coralline algae had a significantly higher percentage cover in control plates and others containing extracts of $A$. fulva and $M$. microsigmatosa (Fig. 5), compared to no occurrence of this algal type in the plates containing $P$. dilatata extract $(\mathrm{p}<0.05)$.

Measurable covers of Dictyotacean algae were observed in all treatments during only 4 weeks, from the $3^{\text {rd }}$ to the $6^{\text {th }}$ (Fig. 6). However, Dictyotacean algae had significantly higher percentage cover in control and in treatments containing extracts of A. fulva and M. microsigmatosa, compared to $P$. dilatata in the $4^{\text {th }}$ week $(\mathrm{p}<0.05)$.

In general, covers by Ectocarpacean algae were very similar on the control and on all treatment plates during the experiment (Fig. 7). However, significantly smaller cover by Ectocarpacean was observed in plates containing extract of $P$. dilatata only in two weeks $\left(4^{\text {th }}\right.$ and $\left.5^{\text {th }}\right)$, compared to remaining control and treatment plates $(\mathrm{p}<$ $0.05)$.

\section{DISCUSSION}

The results described herein on the development of fouling communities represent the usual successional stages reported in the literature (see Wahl, 1989). After about 2-3 weeks of immersion the establishment of biofilm occurred, followed by the establishment of macroscopic organisms.

The pattern of biofilm establishment was similar in all experiments and in the control, demonstrating that none of the invertebrate crude extracts was able to inhibit the establishment of this stage of microfouling. On the other hand, a quite distinct composition of macrofouling was observed in all treatments and in the control.

Whether microfouling is a general prerequisite for subsequent settling has not been determined (Little, 1984). Since the observed biofilm establishment pattern was very similar in all treatments and in the control and since the specific composition of macroscopic foulers was different, we assumed that biofilm may not be important to subsequent succession. 


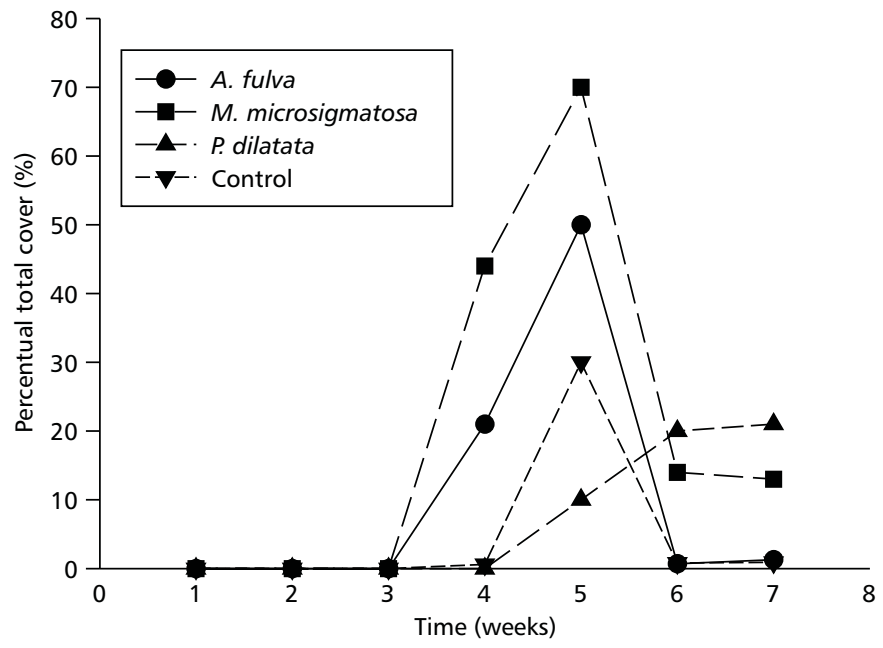

Fig. 4 - Percent cover of the brown alga Colpomenia on control and experimental plates over seven weeks of experiment.

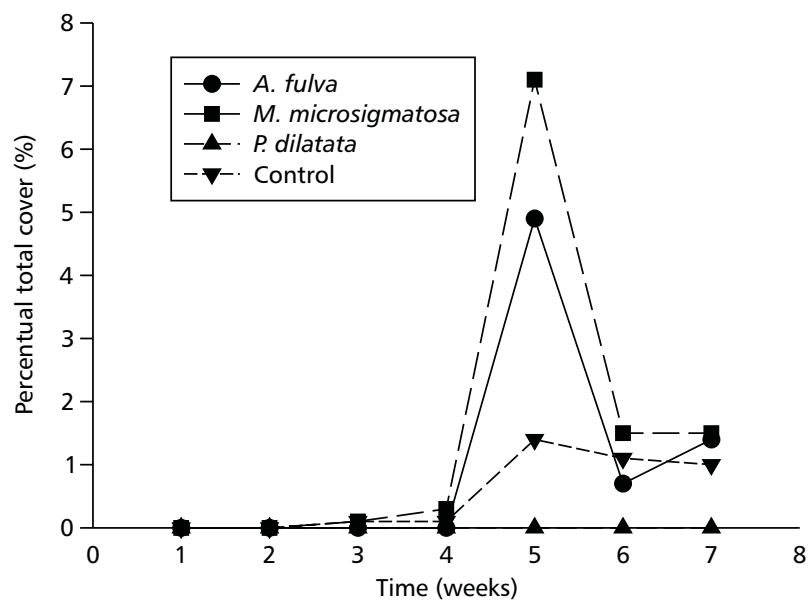

Fig. 5 - Percent cover of coralline algae on control and experimental plates over seven weeks of experiment. 


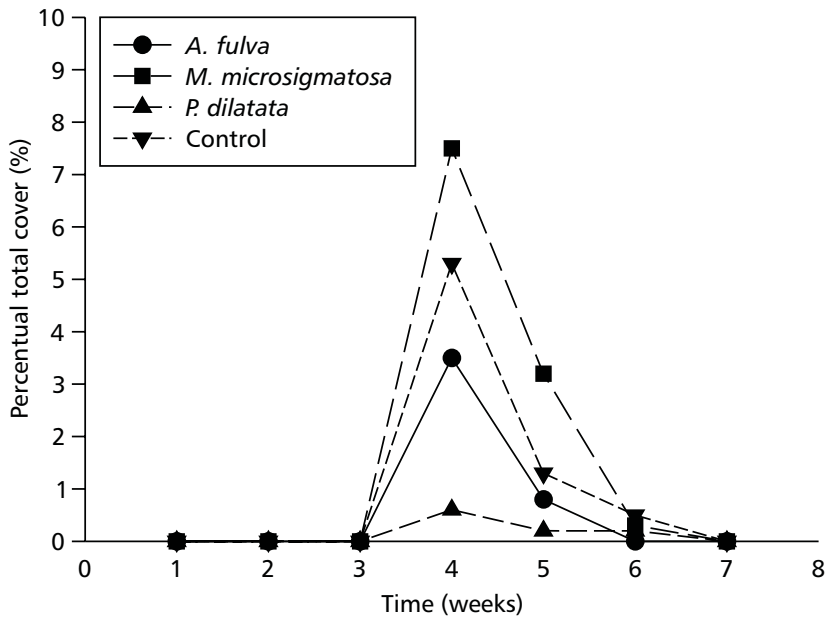

Fig. 6 - Percent cover of Dictyotacean algae on control and experimental plates over seven weeks of experiment.

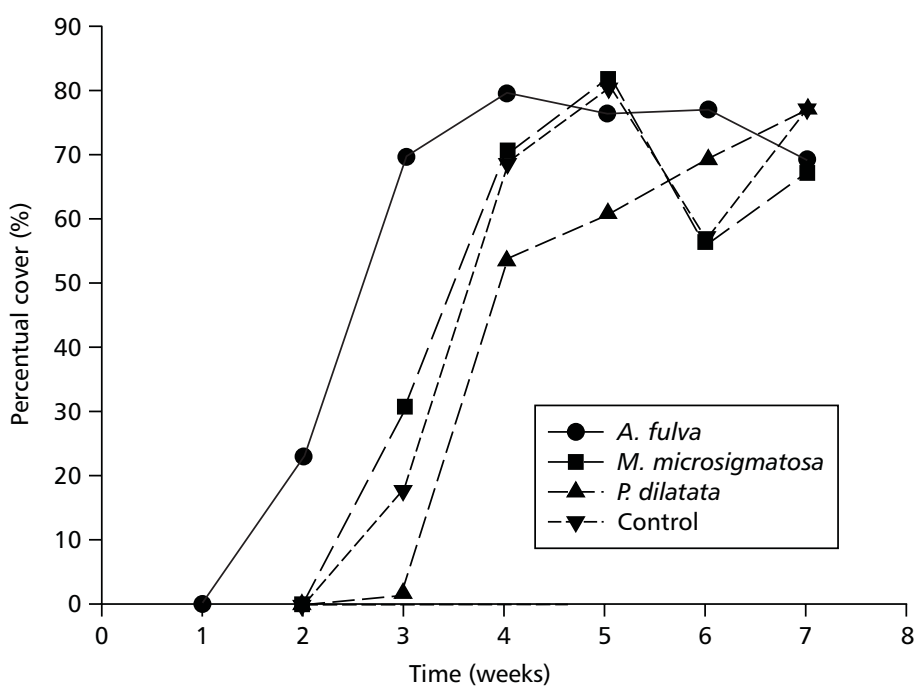

Fig. 7 - Percent cover of Ectocarpacean algae on control and experimental plates over seven weeks of experiment. 
The present study also demonstrated that the crude extract of $A$. fulva did not inhibit the establishment of fouling. However, species of Aplysina are known to produce a diverse array of secondary metabolites (Goo, 1980; Gopichand \& Schmitz, 1979; McMillan et al., 1981; Ziefer et al., 1995; Fendert et al., 1999), exhibiting cytotoxic (Gopichand \& Schmitz, 1979; Compagone et al., 1999), anti-microbial (Goo, 1980) and anti-bacterial activities (Thompson et al., 1985; Muricy et al., 1993; Newbold et al., 1999). Thus, although a number of metabolites from Aplysina species have been screened for biological activity in a variety of pharmacological assays, the value of these assays for predicting the anti-fouling effect may be questionable.

In addition, there is also geographic variation in the numbers and types of secondary metabolites produced by the same species collected in different regions (Pereira et al., 2000). For example, the chemical variation, both qualitative (diversity) and quantitative (concentration), of secondary metabolites appears to decrease at higher latitudes in different populations of the same species (Paul \& Fenical, 1986, 1987; Paul \& van Alstyne, 1988). Thus, it is possible that Brazilian specimens of $A$. fulva possess metabolites other than those found in this species elsewhere.

The sponge A. fulva was found to excrete substances after collection, changing body color from orangy to dark brown. Color changes may be due to oxidative processes in pigments occurring in this sponge species but not in its secondary metabolites. However, the stress due to collection or manipulation can cause both exudation and degradation of secondary metabolites (see Walker, 1981; Thompson et al., 1985; Walker et al., 1985; Muricy et al., 1993).

A TLC (Thin Layer Chromatography) analysis demonstrated that Brazilian specimens of A. fulva produce diverse secondary metabolites, visible both before and after the field assays. Thus, we suppose that secondary metabolites produced by A. fulva on the Brazilian coast are not active against fouling.

The results obtained from plates containing extracts of $M$. microsigmatosa did not exhibit significantly broad anti-fouling activity either. In fact, the crude extract of this species inhibited only the settlement of balanids. In the same way as compounds produced by Aplysina species, secondary metabolites from the genus Mycale are known to exhibit cytotoxic, antiviral, antitumoral, and antimitotic activities (Thompson et al., 1992, 1994; Fusetani et al., 1991; Northcote et al., 1991; Perry et al., 1988, 1990). On the other hand, some studies demonstrated that the crude extract of $M$. microsigmatosa did not exhibit antimicrobial activity (Green et al., 1990; Muricy et al., 1993) or inhibit microorganisms in laboratory assays (Green et al., 1990; Muricy et al., 1993), but in the present study exhibited specific anti-fouling activity against the settlement of balanids.

The crude extracts of $P$. dilatata also inhibited only the establishment of balanids. In fact, the more common fouling organisms were absent or rare on $P$. dilatata observed in the field (the authors, pers. observ.).

The gorgonian $P$. dilatata is an endemic species on the Brazilian coast and is known to produce one sterol (Kelecom et al., 1980) and two nardosinane sesquiterpenes (Kelecom et al., 1990; Fernandes \& Kelecom, 1995), a cembranoid diterpene (Epifanio et al., 1999) and a germacrane sesquiterpene (Martins \& Epifanio, 1998). The cembranoid diterpene is a potent chemical defense against predators on the Brazilian coast and this particular class of compounds has feeding deterrence properties, protecting octocorals from different predators both in tropical and temperate regions (Epifanio et al., 1999).

Diterpene alcohols produced by the brown seaweed Dictyota menstrualis deter feeding by several species of herbivores and may also prevent fouling organisms from colonizing the surface of this alga (Schmitt et al., 1995). Given the multiple ecological functions of some secondary metabolites, it seems unlikely that these metabolites would have evolved in response to consumers only, much less in response to any particular consumer. It is therefore not surprising that secondary metabolites from $P$. dilatata are effective against predators and also prevent the specific establishment of balanids.

Acknowledgments - The National Brazilian Research Council (CNPq, Proc. 62.0470/94-1 and 52.1914/96-5) supported this research. RCP and $\mathrm{RC}$ thank $\mathrm{CNPq}$ for the Productivity Fellowships.

\section{REFERENCES}

BAKUS, G. J., SCHULTE, B., JHU, S., WRIGHT, M., GREEN, M. \& GOMEZ, P., 1985, Antibiosis and antifouling in marine sponges: laboratory versus field studies. Proc. $3^{\text {rd }}$ Int. Sponge Conf., pp. 102-108. 
BINGHAM, B. L. \& YOUNG, C. M., 1991, Influence of sponges on invertebrate recruitment: a field test of allelopathy. Mar. Biol., 109: 19-26.

CALLOW, M. E., 1986, Fouling algae from in-service ships. Bot. Mar., 29: 351-357.

CHAMP, M. A. \& LOWENSTEIN, F. L, 1992, TBT: the dilemma of high technology anti-fouling paints. Oceanus, 35: $69-77$

CLARE, A. S., 1996, Marine natural products antifoulants: status and potential. Biofouling, 9: 211-229.

CRONIN, G., LINDQUIST, N., HAY, M. E. \& FENICAL, W., 1995, Effects of storage and extraction procedures on yields of lipophilic metabolites from the brown seaweeds Dictyota ciliolata and D. menstrualis. Mar. Ecol. Prog. Ser., 119: 265-273.

DA GAMA, B. A. P., PEREIRA, R. C., CARVAlHO, A. G. V. de \& COUTINHO, R., 2002, The effects of seaweed secondary metabolites on biofouling. Biofouling (submitted).

DAVIS, A. R., TARGETT, N. M., McCONNEL O. J. \& YOUNG, C. M., 1989, Epibiosis of marine algae and benthic invertebrates: natural products chemistry and other mechanisms inhibiting settlement and overgrowth. Bioorg. Mar. Chem., 3: 85-114.

DAVIS, A. R. \& WRIGHT, A. E., 1990, Inhibition of larval settlement by natural products from the ascidian, Eudistoma olivaceum (Van Name). J. Chem. Ecol., 16: 1349-1357.

DE NYS, R., STEINBERG, P. D., WILLEMSEN, P., DWORJANYN, S. A., GABELISH, C. L. \& KING, R. J., 1995, Broad spectrum effects of secondary metabolites from the red alga Delisea pulchra in anti-fouling assays. Biofouling, 8: 259-271.

DETHIER, M. N., GRAHAM, E. S., COHEN, S. \& TEAR, L. M., 1993, Visual versus random-point percent cover estimations: 'objective' is not always better. Mar. Ecol. Prog. Ser., 96: 93-100.

DYRINDA, P. E. J., 1986, Defensive strategies of modular organisms. Phil. Trans. R. Soc. (Ser. B), 313: 227-243.

EPIFANIO, R. de A., MARTINS, D. L., VILLAÇA, R. \& GABRIEL, R., 1999, Chemical defenses against fish predation in three Brazilian octocorals: 11,12-epoxypukalide as a feeding deterrent in Phyllogorgia dilatata. J. Chem. Ecol., 26: 2255-2265.

FAULKNER, D. J., 2001, Marine natural products. Nat. Prod. Rep., 18: 1-49.

FENDERT, T., WRAY, V., VAN SOEST, R. W. M. \& PROKSCH, P., 1999, Bromoisoxazoline alkaloids from the Caribbean sponge Aplysina insularis. J. Biosc., 54: 246-252.

FERNANDES, L. \& KELECOM, A., 1995, A further nardosinane sesquiterpene fro the gorgonian Phyllogorgia dilatata (Octocorallia, Gorgonacea). Ann. Acad. Bras. Ci., 67: 171173.
FOSTER, M. S., HARROLD, C. \& HARDIN, D. D., 1991, Point versus photo quadrat estimates of the cover of sessile marine organisms. J. Exp. Mar. Biol. Ecol., 146: 193-203.

FUSETANI, N., SUGAWARA, T. \& MATSUNAGA, S., 1991, Cytotoxic metabolites of the marine sponge Mycale adhaerens Lambe. J. Org. Chem., 56: 4971-4974.

GERHART, D. J., 1986, Prostaglandin A $\mathrm{A}_{2}$ in the Caribbean gorgonian Plexaura homomalla: evidence against allelopathic and anti-fouling roles. Biochem. Syst. Ecol., 14: 417-421.

GERHART, D. J., RITTSCHOF, D. \& MAYO, S. W., 1988, Chemical ecology and the search for marine antifoulants. Studies of a predator-prey symbiosis. J. Chem. Ecol., 14: 1905-1917.

GOO, Y. M., 1980, Constituents of Aplysina fistularis. Dissertation Abstracts International, 41(2): 553.

GOPICHAND, Y. \& SCHMITZ, F. J., 1979, Marine natural products: fistularin-1, $-2,-3$ from the sponge Aplysina fistularis forma fulva. Tetrahedron Lett., 41: 3921-3924.

GREEN, G., GOMEZ, P. \& BAKUS, G. J., 1990, Antimicrobial and ichtyotoxic properties of marine sponges from Mexican waters. In: K. Ruetzler (ed.), New perspectives in sponge biology. Smithsonian Institution Press, Washington DC, pp. 109-114.

HENRIKSON, A. A. \& PAWLIK, J. R., 1995, A new antifouling assay method: results from field experiments using extracts of four marine organisms. J. Exp. Mar. Biol. Ecol., 194: $157-165$.

HENRIKSON, A. A. \& PAWLIK, J. R., 1998, Seasonal variation in biofouling of gels containing extracts of marine organisms. Biofouling, 12: 245-255.

KELECOM, A., SOLÉ-CAVA, A. M. \& KANNENGIESER, G. J., 1980, Occurrence of 23,24-dimethylcholesta-5,22dien-3b-ol in the Brazilian gorgonian Phyllogorgia dilatata (Octocorallia, Gorgonacea) and its associated zooxantella. Bull. Soc. Chim. Bel., 89: 1013-1014

KELECOM, A., PERES, M. B. \& FERNANDES, L., 1990, A new nardosinane sesquiterpene from the Brazilian endemic gorgonian Phyllogorgia dilatata. J. Nat. Prod., 53: 750-752.

KJELLEBERG, S., STEINBERG, P. D., GIVSKOV, M., GRAM, L., MANEFIELD, M. \& DE NYS, R., 1997, Do marine natural products interfere with prokaryotic AHL regulatory systems? Aq. Microciol. Ecol., 13: 85-93.

LITTLE, B. J., 1984, Succession in microfouling. In: J. D. Costlow \& R. C. Tipper (eds.), Marine biodeterioration: an interdisciplinary study. Naval Institute Press. Annapolis, Maryland, pp. 63-67.

MARTIN, D. \& URIZ, M. J., 1993, Chemical bioactivity of Mediterranean benthic organisms against embryos and larvae of marine invertebrates. J. Exp. Mar. Biol. Ecol., 173: $11-27$.

MARTINS, D. L. \& EPIFANIO, R. de A., 1998, A new germacrane sesquiterpene from the Brazilian endemic gorgonian Phyllogorgia dilatata Esper. J. Braz. Chem. Soc., 9: 586-591. 
McMILLAN, J. A., PAUL, I. C., GOO, Y. M., RINEHART Jr., K. L.; KRUEGER, W. C. \& PSCHIGODA, L. M. 1981, New X-ray study of aerothionin from Aplysina fistularis Pallas. Tetrahedron Lett., 22: 39-42.

MICHALEK, K. \& BOWDEN, B. F., 1997, A natural algacide from soft coral Sinularia flexibilis (Coelenterata, Octocorallia, Alcyonacea). J. Chem. Ecol., 23: 259-273.

MURICY, G., HADJU, E., ARAUJO, F. V. \& HAGLER, A. N., 1993, Antimicrobial activity of southwestern Atlantic shallow-water marine sponge (Porifera). In: M. J. Uriz \& K. Rutzler (eds.), Recent advances in ecology and systematics of sponges. Instituto de Ciencias del Mar, Barcelona, Spain), pp. 427-432.

NEWBOLD, R. W., JENSEN, P. R., FENICAL, W. \& PAWLIK, J. R., 1999, Antimicrobial activity of Caribbean sponge extracts. Aq. Microb. Ecol., 19: 279-284.

NORTHCOTE, P. T., BLUNT, J. W. \& MUNRO, M. H. G., 1991, Pateamine: a potent cytotoxin from the New Zealand marine sponge. Tetrahedron Lett., 32: 6411-6414.

PAUL, V. J. \& FENICAL, W., 1986, Chemical defense in tropical green algae, order Caulerpales. Mar. Ecol. Prog. Ser., 34: 157-169.

PAUL, V. J. \& FENICAL, W., 1987, Natural products chemistry and chemical defense in tropical marine algae of the phylum Chlorophyta, vol. 1, pp. 1-29. In SCHEUER, P. J. (ed.), Bioorganic Marine Chemistry. Springer-Verlag, Berlin.

PAUL, V. J. \& VAN ALSTYNE, K. L., 1988, Use of ingested algal diterpenoids by Elysea halimedae Macnae (Opistobranchia: Ascoglossa) as antipredator defenses. J. Exp. Mar. Biol. Ecol., 119: 15-29.

PAWLIK, J. R., 1992, Chemical ecology of the settlement of benthic marine invertebrates. Oceanogr. Mar. Biol. Ann. Rev., 30: 373-335.

PEREIRA, R. C., CAVALCANTI, D. N. \& TEIXEIRA, V. L., 2000, Effect of secondary metabolites from the tropical Brazilian brown alga Dictyota menstrualis on the feeding by amphipod herbivores. Mar. Ecol. Prog. Ser., 205: 95-100.

PERRY, N. B., BLUNT, J. W., MUNRO, M. H. G. \& PANNELL, L. K., 1988, Mycalamide A, an antiviral compound from a New Zealand sponge of the genus Mycale. J. Am. Chem. Soc., 110: 4850-4851.

PERRY, N. B., BLUNT, J. W., MUNRO, M. H. G. \& THOMPSON, A. M., 1990, Antitumoral and tumor agents from a New Zealand sponge, Mycale sp. 2. Structures and solution conformations of mycalides A and B. J. Org. Chem., 55: 223-227.

RITTSCHOF, D., HOOPER, I. R. \& COSTLOW, J. D., 1986, Barnacle settlement inhibitors from sea pansies, Renilla reniformis. Bull. Mar. Sci., 39: 376-382.

SAFRIEL, U. N., COHEN, Y., EREZ, N., GATENO, D., KEASAR, T. \& DOLEY, Y., 1993, Biological control of marine biofouling. Oebalia, 19: 193-199.

SCHMITT, T. M., HAY, M. E. \& LINDQUIST, N., 1995, Constraints on chemically mediated coevolution: multiple functions for seaweed secondary metabolites. Ecology, 76: $107-123$.
SEARS, M. A., GERHART, D. J. \& RITTSCHOF, D., 1990, Anti-fouling agents from marine sponge Lissonderyx isodictyalis Carter. J. Chem. Ecol., 16: 791-799.

STEINBERG, P. D., DE NYS, R. \& KJELLEBERG, S., 1998, Chemical inhibition of epibiota by Australian seaweeds. Biofouling, 12: 227-244.

TARGETT, N. M., 1988, Allelochemistry in marine organisms: chemical fouling and antifouling strategies. In: M. F. Thompson, R. Sarojini \& R. Nagabhushanam (eds.), $M a-$ rine biodeterioration: advanced techniques applicable to Indian Ocean. Oxford \& IBH Publishing Co., New Deli, pp. 609-617.

THOMPSON, J. E., WALKER, R. P. \& FAULKNER, D. J., 1985, Screening and bioassays for biologically-active substances from forty marine sponges from San Diego, California, USA. Mar. Biol., 88: 11-21.

THOMPSON, A. M., BLUNT, J. W., MUNRO, M. H. G. \& CLARK, B. M., 1994, Chemistry of the mycalamides, antiviral and antitumor compounds from a marine sponge. Part 4. Reactions of mycalamide A and alkyl derivatives with basic nucleophiles. J. Chem. Soc. Perkin Trans., 1: 1025-1031.

THOMPSON, A. M., BLUNT, J. W., MUNRO, M. H. G., PERRY, N. B. \& PANNELL, L. K., 1992, Chemistry of the mycalamides antiviral and antitumor compounds from the marine sponge. Part 3. Acyl, alkyl and silyl derivatives. J. Chem. Soc. Perkin Trans., 1: 1335-1342.

URIZ, M. J., MARTIN, D. \& ROSELL, D., 1992, Relationships of biological and taxonomic characteristics to chemically mediated bioactivity in Mediterranean littoral sponges. Mar. Biol., 113: 287-297.

WHOI, 1967, The effects of fouling. In: US Naval Institute (ed.), Marine fouling and its prevention, Contrib n. 580. Woods Hole Oceanographic Institution, Annapolis, Maryland, p. 388.

WAHL, M., 1989, Marine epibiosis. I. Fouling and anti-fouling: some basic aspects. Mar. Ecol. Prog. Ser., 58: 175-189.

WALKER, R. P., 1981, The chemical ecology of some sponges and nudibranchs from San Diego. University of California, San Diego, Dissertation Abstracts International, 42(9).

WALKER, R. P., THOMPSON, J. E. \& FAULKNER, D. J., 1985, Exudation of biologically-active metabolites in the sponge Aplysina fistularis. II. Chemical evidence. Mar. Biol., 88: 27-32.

WILLEMSEN, P. R., 1994, The screening of sponge extracts for anti-fouling activity using a bioassay with laboratoryreared cyprid larvae of the barnacle Balanus amphitrite. Int. Biodeterior. Biodegrad., 34: 361-373.

WILLEMSEN, P. R., 1996, Antifoulants from marine invertebrates: Sponges. In: Biofouling: problems and solutions. Proc. Int. Workshop. New South Wales, pp. 87-92.

WILLEMSEN, P. R. \& FERRARI, G. M., 1993, The search for alternative anti-fouling methods: how to learn from nature? A pilot study. Oebalia, 19: 485-494.

ZIEFER, M. S., VIEIRA, R. P., MULLOY, B. \& MOURÃO, P. A. S., 1995, A novel acidic glycogen extract from the marine sponge Aplysina fulva (Porifera, Demospongiae). Carboh. Res., 274: 233-244. 